Milomirka Škrba ${ }^{1 *}$, Zoran Obrenović ${ }^{1,2}$, Aleksandar Došić1, Miladin Gligorić ${ }^{1}$, Biljana Đurić ${ }^{2}$, Ivan Savić ${ }^{3}$

${ }^{1}$ University of East Sarajevo, Faculty of Technology Zvornik, Zvornik, Republic of Srpska, Bosnia and Herzegovina, ${ }^{2}$ Alumina doo, Zvornik, Republic of Srpska, Bosnia and Herzegovina, ${ }^{3}$ University of Niš, Faculty of Technology in Leskovac, Leskovac, Republic of Serbia
Scientific paper

ISSN 0351-9465, E-ISSN 2466-2585

UDC: 661.183.6:544.726:546.131

https://doi.org/10.5937/zasmat2103155S

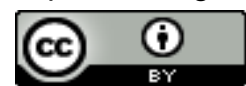

Zastita Materijala 62 (3)

155 - 165 (2021)

\title{
Ion exchange of sodium with hydrochloric acid in ZSM-5 zeolite
} \begin{abstract}
ZSM-5 zeolites are highly silicate materials that have significant application in catalytic processes in petrochemistry, especially due to their high selectivity. Most reactions in the petrochemical industry are acid-catalyzed. The acidic properties of zeolite depend on the number of acid centers, i.e. the presence of hydrogen ions, and therefore, in this paper the possibility of reducing the sodium content in the pores of high silicate zeolite ZSM-5 with the modulus $\left(\mathrm{SiO}_{2} / \mathrm{Al}_{2} \mathrm{O}_{3}=1000\right)$ will be investigated, by applying ion exchange with hydrochloric acid. Chemical analysis of samples before and after ion exchange, and application of instrumental methods of X-Ray diffraction, FT-IR spectroscopy, and SEM analysis monitored the influence of the quantity of hydrogen ions on the chemical composition and the structure of ZSM-5 zeolite at different acid concentrations and at different exchange times.

It has been shown that the application of ion exchange with hydrochloric acid can reduce the sodium content in zeolite. Even with the application of $5 \% \mathrm{HCl}$ for 6 hours, the content of sodium in the zeolite is reduced by over $98 \%$. A similar effect is achieved by applying more concentrated hydrochloric acid solutions for a shorter ion exchange time. By prolonging the ion exchange time, there are no significant changes in terms of the final ion exchange. On the other hand, the application of $\mathrm{HCl}$ solutions of higher concentrations leads to a slight decrease in the aluminum content in the zeolite, which may partially affect the structural stability of the zeolite. The results obtained by FT-IR and SEM analysis and X-Ray diffraction confirm the possibility of ion exchange with hydrochloric acid, without significant changes in the crystal structure of the zeolite.
\end{abstract}

Keywords: zeolite, sodium ion exchange, characterization of H-ZSM-5, XRD, FT-IR, SEM.

\section{INTRODUCTION}

Zeolites are crystalline aluminosilicates composed of an ordered system of channels and cavities. The crystal lattice of zeolite is built of $\mathrm{TO}_{4}$ tetrahedra, where $\mathrm{T}$ represents the $\mathrm{Al}^{3+}$ or $\mathrm{Si}^{4+}$ ion(s), interconnected by oxygen atoms [1-3]. Since the silicon atom has four valence electrons, $\mathrm{SiO}_{4}$ tetrahedra are electroneutral, but when the $\mathrm{Si}^{4+}$ ion is replaced with $\mathrm{Al}^{3+}$ in the center of the tetrahedron, the crystal lattice becomes negatively charged. The negative charge of the lattice is neutralized by cations of alkali and alkaline earth metals, or hydrogen ions, located in the pore openings $[4,5]$.

Corresponding author: Milomirka Škrba

E-mail: milomirka.skrba@tfzv.ues.rs.ba

Paper received: 14. 04. 2021.

Paper accepted: 28. 05. 2021.

Paper is available on the website: www.idk.org.rs/journal
The chemical composition of the zeolite can be represented by following the formula $[6,7]$ :

$$
M_{x / n}\left[A I_{x} S_{y} \mathrm{O}_{2(x+y)}\right] \cdot p \mathrm{H}_{2} \mathrm{O}
$$

where:

$\mathrm{M}$ - extra-framework cation ( $\mathrm{Na}, \mathrm{K}, \mathrm{Li})$ and/or $(\mathrm{Ca}$, $\mathrm{Mg}, \mathrm{Ba}, \mathrm{Sr}$ ),

$\mathrm{n}$ - cation charge,

$x$ - number of aluminium atoms,

$y$ - number of silicon atoms, and

$p-$ number of water molecules in each unit cell; $y / x$ $=1-6, \mathrm{p} / \mathrm{x}=1-4$.

Zeolites of the ZSM type (Zeolite Socony Mobil or Zeolite Sieve of Molecular porosity) belong to the group of MFI zeolites, and they have the largest application in the petrochemical industry as catalysts and adsorbents. The crystal lattice of these high silicate materials consists of two types of three-dimensional channels whose openings are 
the size of 10-membered rings. The first channels are straight and elliptical $(0.51 \times 0.57 \mathrm{~nm}$ in diameter), while the second intersect the right channels at right angles, and they are sinusoidal and circular in cross-section $(0.54 \times 0.56 \mathrm{~nm}$ in diameter) [8-10].

Zeolites are the most important inorganic cation ion exchangers in which the crystallographic positions of the cations affect the rate and mechanism of ion exchange. Because extraframework cations are bound by weak electrostatic forces to water molecules or structural atoms of silicon or aluminum, they are extremely mobile and can be easily exchanged in ion exchange processes without disturbing the crystal structure. However, this also depends on the chemical composition and crystal structure of a particular zeolite [11-14].

Since ZSM-5 zeolite, is mostly used in the petrochemical industry [15], especially in hydrocracking reactions, due to its catalytic action, it is important to provide a sufficient amount of acid sites to improve their catalytic action. The number and quantity of Brønsted and Lewis acid centers, as well as their ratio, affect the acid-base properties of zeolites. In addition, the catalytic activity and selectivity of ZSM- 5 zeolite depend on the chemical composition of the starting materials for synthesis, degree of crystallinity, temperature and crystallization time, type of template, and many other factors $[9,16,17]$.

\section{EXPERIMENTAL PART}

ZSM-5 zeolite with a molar ratio of $\mathrm{SiO}_{2} / \mathrm{Al}_{2} \mathrm{O}_{3}=$ 1000 , from the Plant for the production of special zeolites, was used as a starting sample, where amorphous silica, with particle size distribution up to $80 \mu \mathrm{m}$, is most often used as a source of silicon, and sodium -aluminate is used as a source of aluminum, in powder form. The synthesis of ZSM-5 zeolites mostly involves the use of the so-called templates that fill the space in the zeolite structure, to direct the upbuilding of the crystal lattice during the crystallization process or as charge stabilizers in the zeolite structure, and can also affect the kinetics of zeolite synthesis [16]. In this case, tetrapropylammonium bromide (TPABr) was used as a template. During each synthesis, a certain amount of previously produced zeolite without specific characteristics is added, to act as a crystallization germ, as well as a certain amount of water glass, which also contains a significant precentage of silicon, and caustic soda, which provides alkalinity of the reaction medium.
The initial zeolite sample was calcined to $550^{\circ} \mathrm{C}$. The ion exchange process of ZSM-5 zeolite was performed in the Alumina Research Laboratory. A 20\% suspension of calcined zeolite and hydrochloric acid was prepared, and then stirred on a magnetic stirrer at $90^{\circ} \mathrm{C}$ for 1,3 , and 6 hours. Hydrochloric acid concentrations ranged from 5 to $15 \%$. In the ion exchange reaction, $\mathrm{Na}^{+}$ ions were exchanged with $\mathrm{H}^{+}$ions.

After ion exchange was completed, vacuum filtration was performed and the filter cake was rinsed. The sample was then dried at $105^{\circ} \mathrm{C}$ in an oven. The loss on ignition was determined according to the standard method ISO 6606/1986.

Multi - elemental analysis of the concentrations of metals was used for the chemical analysis of samples, i.e. determination of changes in metal contents, using the ICP - OES SPEKTROGE$N E S I S$ device. The determination of the content of individual metals was carried out according to the standard method EN-ISO 11885.

The structural characteristics of the zeolite samples were determined using diffractograms recorded on an X-ray diffractometer BRUKER D4 ENDEAVOR with an $\mathrm{X}$-ray tube, and a copper anticathode, using CuKa radiation at the wavelengt $\lambda=1.54060 \AA$. By comparing the areas of peaks that are characteristic of the ZSM-5 zeolite standard with a modulus of 400 , i.e. the standard values from the crystallographic base of the laboratory, and the tested samples with a modulus of 1000 , the degree of crystallinity of the sample was quantified. The degree of crystallinity of zeolite samples was determined according to the standard test method ASTM D5758-1.

In addition to X-ray diffraction (XRD), structural changes, as well as reactions within the pores of zeolite can be observed using FT-IR spectroscopy (Fourier - transform infrared spectroscopy). For the purpose of the present study, the FT-IR spectrometer SHIMADZU was used. The recording was performed in the range of 500 to $4000 \mathrm{~cm}^{-1}$.

Changes in the morphological characteristics of the zeolite samples were monitored using scanning electron microscopy (SEM) on the MIRA3 TESCAN device, at a voltage of $20 \mathrm{kV}$, and a magnification of 10000 times.

\section{RESULTS AND DISCUSSION}

Table 1 shows the results obtained by chemical analysis of the samples of non-calcined and calcined zeolite ZSM-5 with the $\mathrm{SiO}_{2} / \mathrm{Al}_{2} \mathrm{O}_{3}$ ratio of 1000. 
Table 1. Chemical composition of the starting sample of non-calcined and calcined ZSM-5 zeolites

Tabela 1. Hemijski sastav polaznog uzorka nekalcinisanog i kalcinisanog ZSM-5 zeolita

\begin{tabular}{|c|c|c|c|c|}
\hline Sample & Loss on ignition [\%] & $\% \mathrm{Na}$ & $\% \mathrm{Al}_{2} \mathrm{O}_{3}$ & $\% \mathrm{SiO}_{2}$ \\
\hline non-calcined ZSM-5 & 13.60 & 1.03 & 0.17 & 98.06 \\
\hline calcined ZSM-5 & 3.98 & 1.11 & 0.20 & 98.14 \\
\hline
\end{tabular}

Calcination of ZSM- 5 zeolite at $550^{\circ} \mathrm{C}$ removes the used TPABr template and crystal water, as a result of which the loss on ignition is significantly reduced, while the content of sodium, aluminium, and silicon does not change significantly (Table 1).

Table 2. The effect of ion exchange time and $\mathrm{HCl}$ concentration on sodium and $\mathrm{Al}_{2} \mathrm{O}_{3}$ contents

Tabela 2. Uticaj vremena jonske izmjene i koncentracije $\mathrm{HCl}$ na sadržaj natrijuma i $\mathrm{Al}_{2} \mathrm{O}_{3}$

\begin{tabular}{|c|c|c|c|c|c|}
\hline Sample & $\begin{array}{c}\text { Ion exchange time } \\
{[\mathrm{h}]}\end{array}$ & $\begin{array}{c}\text { Acid concentration } \\
{[\%]}\end{array}$ & $\begin{array}{c}\text { Loss on ignition } \\
{[\%]}\end{array}$ & $\% \mathrm{Na}$ & $\% \mathrm{Al}_{2} \mathrm{O}_{3}$ \\
\hline ZSM-5 5\% HCl 6h & 6 & 5 & 0.61 & 0.019 & 0.17 \\
\hline ZSM-5 7\% HCl 6h & 6 & 7 & 0.64 & 0.012 & 0.15 \\
\hline ZSM-5 $10 \% \mathrm{HCl} 1 \mathrm{~h}$ & 1 & 10 & 0.76 & 0.018 & 0.15 \\
\hline ZSM-5 $10 \% \mathrm{HCl} 3 \mathrm{~h}$ & 3 & 10 & 0.76 & 0.014 & 0.14 \\
\hline ZSM-5 10\% HCl 6h & 6 & 10 & 0.59 & 0.010 & 0.13 \\
\hline ZSM-5 12\% HCl 6h & 6 & 12 & 0.62 & 0.014 & 0.13 \\
\hline ZSM-5 $15 \% \mathrm{HCl} 1 \mathrm{~h}$ & 1 & 15 & 1.00 & 0.021 & 0.13 \\
\hline ZSM-5 $15 \% \mathrm{HCl} 3 \mathrm{~h}$ & 3 & 15 & 0.83 & 0.016 & 0.12 \\
\hline ZSM-5 $15 \% \mathrm{HCl} 6 \mathrm{~h}$ & 6 & 15 & 0.62 & 0.012 & 0.11 \\
\hline
\end{tabular}

As can be seen from the data shown in Table 2 and Figure 1, the action of hydrochloric acid, of different concentrations, on the initial calcined zeolite sample results in the exchange of sodium ions with hydrogen ions. With sodium ion exchange already with $5 \% \mathrm{HCl}$, at a change time of 6 hours, there is a significant reduction in the sodium content of the zeolite of over $98 \%$. With a more concentrated $\mathrm{HCl}$ solution, at a change time of $6 \mathrm{~h}$, there are no significant changes in terms of the final ion exchange of sodium, i.e. the reduction of the sodium content in the zeolite is certainly over $98 \%$.

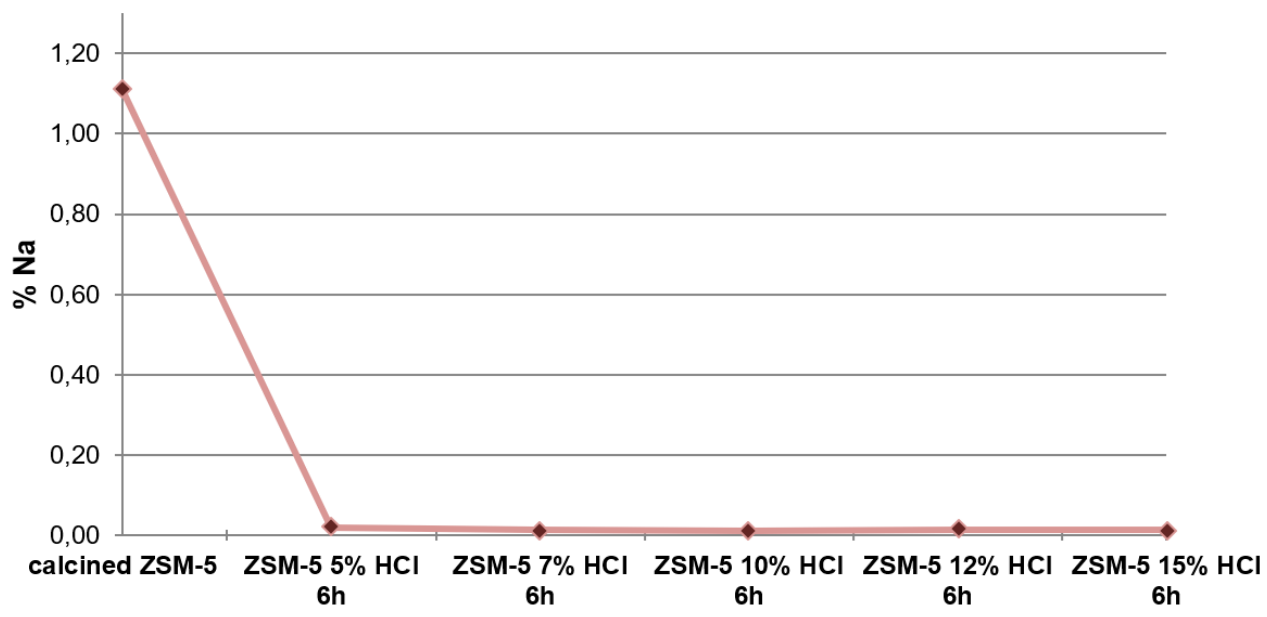

Figure 1. The ion exchange of sodium with hydrochloric acid of different concentrations

Slika 1. Jonska izmjena natrijuma sa hlorovodoničnom kiselinom različitih koncentracija 
Figures 2 - 3 show the influence of ion exchange time on the reduction of the sodium content in zeolite, and it can be seen that the process of sodium ion exchange with hydrogen ions is extremely efficient, already at an ion exchange time of 1 hour, with $10 \%$ and $15 \% \mathrm{HCl}$. By further prolonging the ion exchange time, there are no significant changes in the sodium content in the zeolite (Table 2).

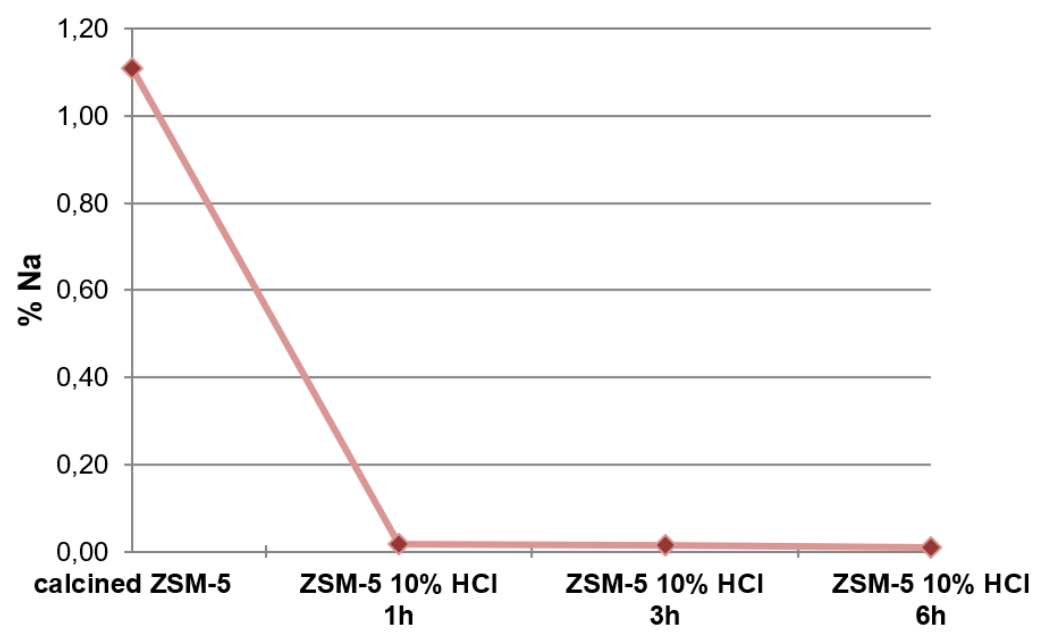

Figure 2. The ion exchange of sodium with $10 \% \mathrm{HCl}$ for varying exchange times

Slika 2. Jonska izmjena natrijuma pri različitim vremenima jonske izmjene sa $10 \% \mathrm{HCl}$

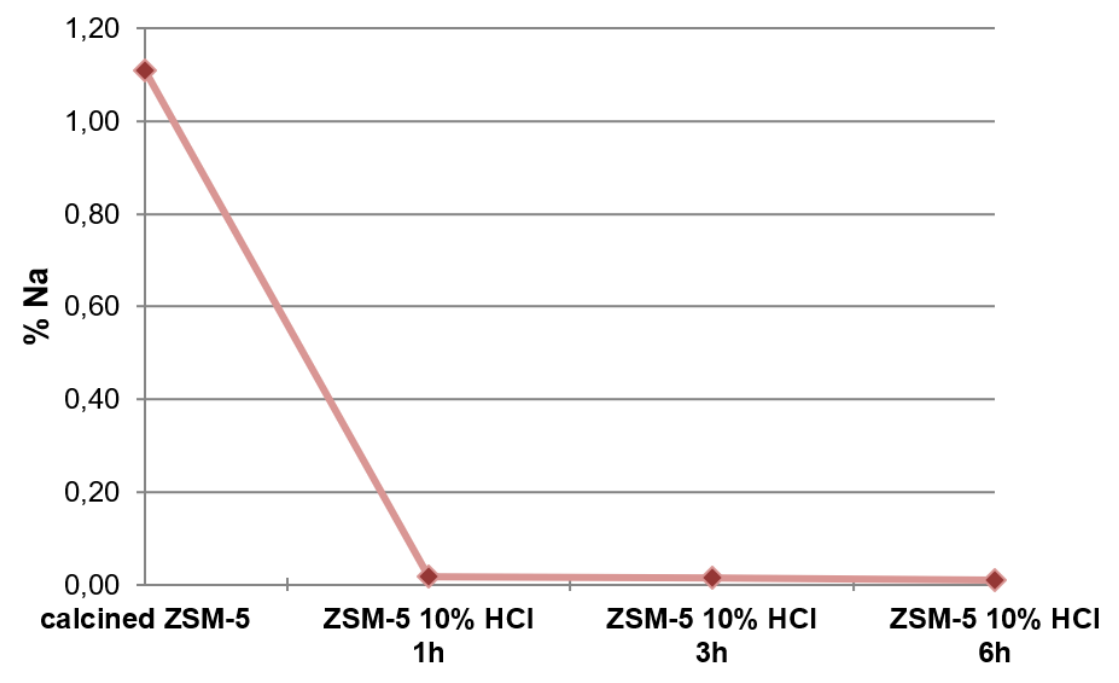

Figure 3. The ion exchange of sodium with $15 \% \mathrm{HCl}$ for varying exchange times

Slika 3. Jonska izmjena natrijuma pri različitim vremenima jonske izmjene sa $15 \% \mathrm{HCl}$

In the case of ion exchange with $\mathrm{HCl}$, there is a slight decrease in the aluminium content at lower concentrations of acid, because the acid is mostly spent on the exchange of sodium ions (Figure 4). Figure 4 shows the effect of $\mathrm{HCl}$ concentration on the reduction of the aluminium content in zeolite during ion exchange. It is evident that increasing the $\mathrm{HCl}$ concentration slightly reduces the aluminium content in the zeolite after ion exchange; however, this can affect the structural stability of the zeolite itself.

Figures 5 and 6 show the effect of $\mathrm{HCl}$ ion exchange time on the reduction of aluminum content in the zeolite with $10 \% \mathrm{HCl}$ and $15 \% \mathrm{HCl}$. During the ion exchange, the aluminium content decreases, with $\mathrm{HCl}$ combining with the aluminium from the zeolite crystal lattice, as a result of which the aluminium is partially removed in the form of chloride. 


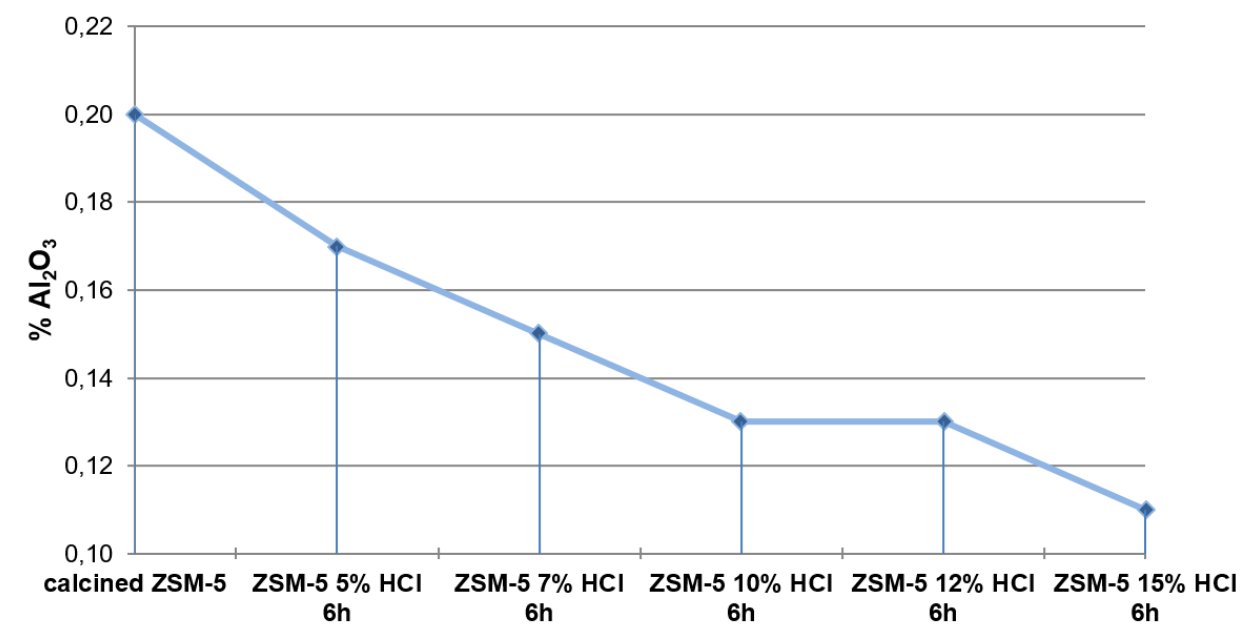

Figure 4. Change in $\mathrm{Al}_{2} \mathrm{O}_{3}$ content at different concentrations of hydrochloric acid Slika 4. Promjena sadržaja $\mathrm{Al}_{2} \mathrm{O}_{3}$ pri različitim koncentracijama hlorovodonične kiseline

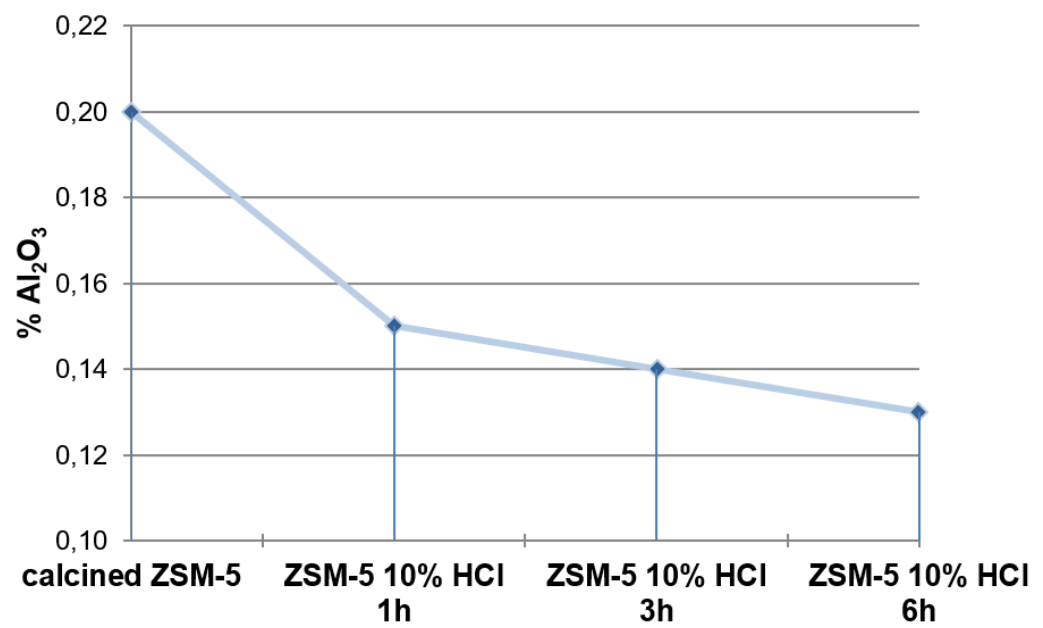

Figure 5. Change in $\mathrm{Al}_{2} \mathrm{O}_{3}$ content at different ion exchange times with $10 \% \mathrm{HCl}$ Slika 5. Promjena sadržaja $\mathrm{Al}_{2} \mathrm{O}_{3}$ pri različitim vremenima jonske izmjene sa $10 \% \mathrm{HCl}$

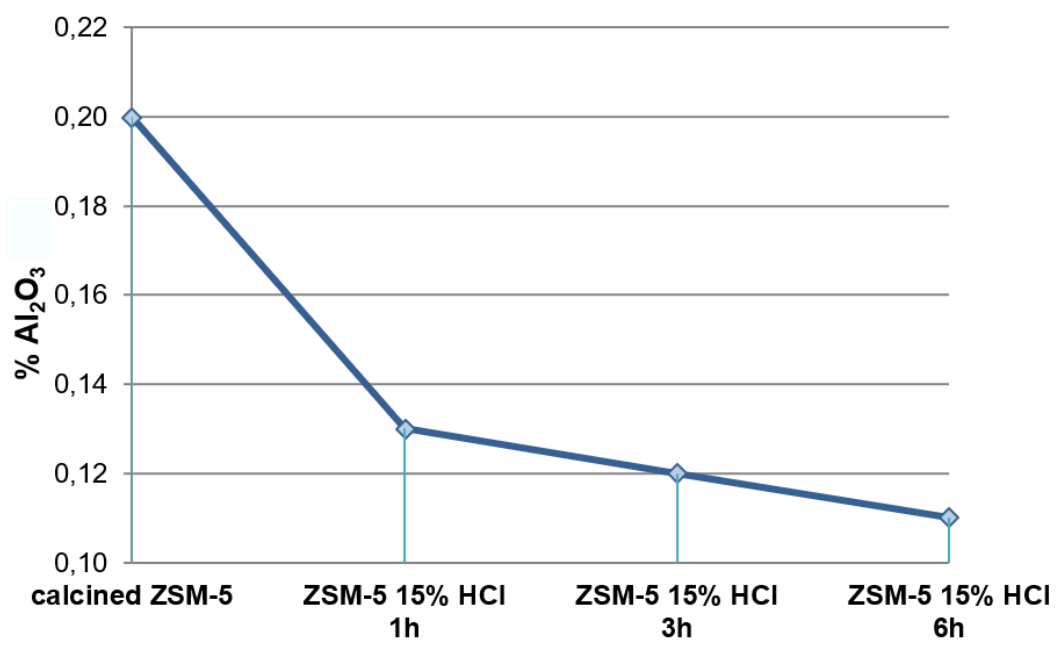

Figure 6. Change in $\mathrm{Al}_{2} \mathrm{O}_{3}$ content at different ion exchange times with $15 \% \mathrm{HCl}$ Slika 6. Promjena sadržaja $\mathrm{Al}_{2} \mathrm{O}_{3}$ pri različitim vremenima jonske izmjene sa $15 \% \mathrm{HCl}$ 
By comparing the obtained FT-IR spectra for non-calcined and calcined zeolite, certain changes in the intensity of the characteristic peaks for zeolites can be observed (Figure 7). Absorption bands occurring at wavelengths 788,1084 , and $1218 \mathrm{~cm}^{-1}$ correspond to the presence of tetrahedral $\mathrm{SiO}_{4}$ units. With calcined zeolite, more intense peaks are obtained at wavelengths of 543 $\mathrm{cm}^{-1}$ (vibrations due to stretching of external bonds of $\mathrm{AlO}_{4}$ and $\mathrm{SiO}_{4}$ tetrahedra), and $1084 \mathrm{~cm}^{-1}$ (internal asymmetric vibrations of Si-O-T bonds), which may be due to higher stresses in the crystal lattice, due to the removal of templates and crystal water by the calcination process. The intensities of the absorption bands at a wavelength of $788 \mathrm{~cm}^{-1}$ (symmetrical stretching of external bonds that maintain the structure) and $1218 \mathrm{~cm}^{-1}$ (asymmetric stretching, vibrations of external bonds in structures containing, so-called pentasiles, present in ZSM-5 zeolite) are reduced in the calcined zeolite. At a wavelength of $1621 \mathrm{~cm}^{-1}$, an exothermic process takes place, which refers to water desorption, and the intensity of the absorption band at that wavelength is lower in calcined zeolite due to the vibration reductions of the $\mathrm{H}-\mathrm{OH}$ bond $[9,18,19]$.

Calcination partially removes TPABr templates, which is evident from the decrease in the intensity of the absorption band in the calcined zeolite in the wavelength range $3431-3625 \mathrm{~cm}^{-1}$. In addition, the doublet occurring at 2330 and $2340 \mathrm{~cm}^{-1}$ indicates $\mathrm{CO}_{2}$ formation, upon complete oxidation of the propyl chains of $\mathrm{TPA}^{+}$molecules $[9,20]$.

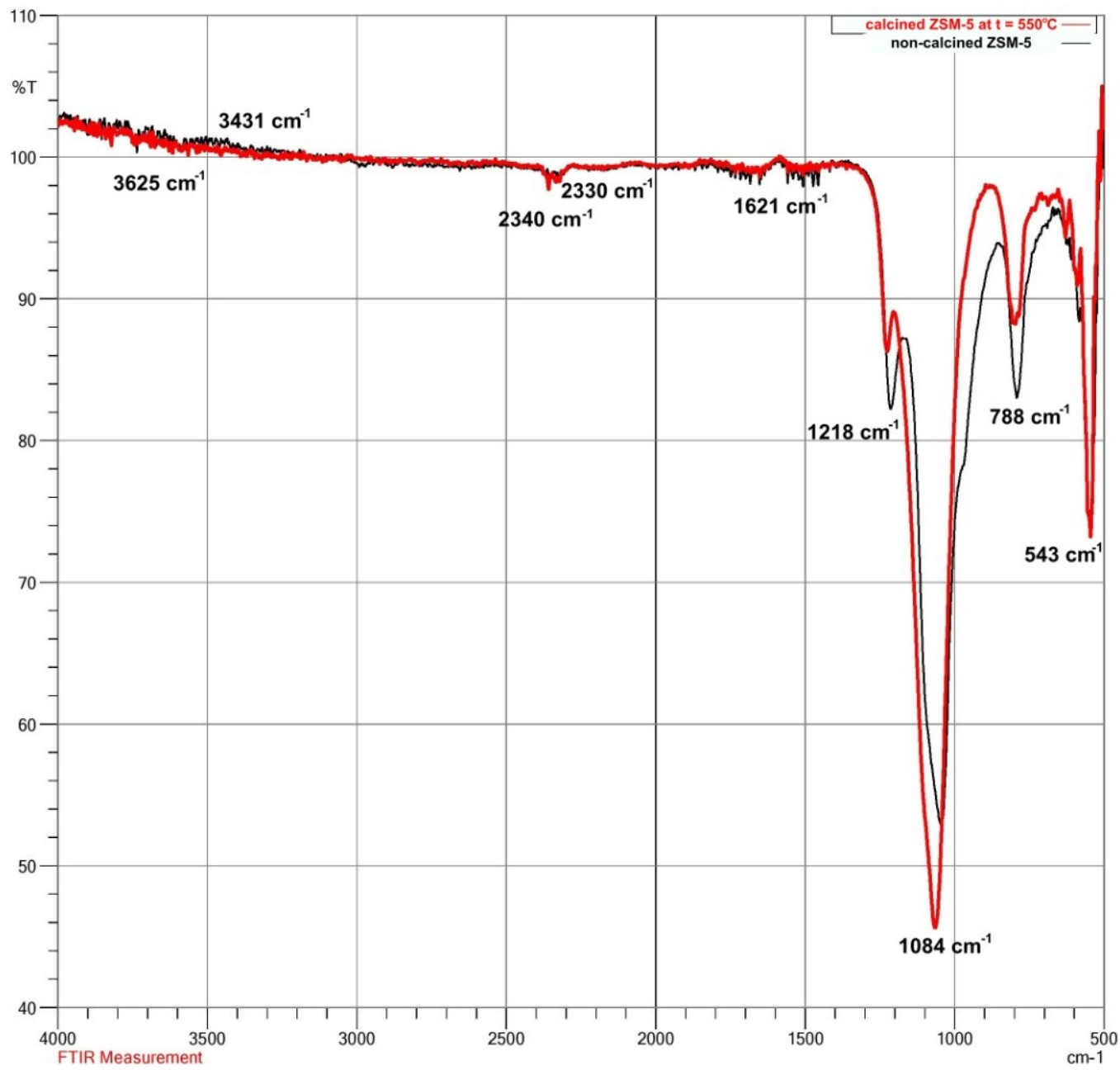

Figure 7. FT-IR spectra of non-calcined (-) and calcined (-) zeolite ZSM-5

Slika 7. FT-IR spektri nekalcinisanog (-) i kalcinisanog (-) zeolita ZSM-5

Based on the FT-IR spectra shown in Figure 8, the coincidence of the characteristic peaks of the analyzed samples of ZSM-5 zeolite modified with
$\mathrm{HCl}$ of different concentrations and the calcined sample of ZSM-5 zeolite can be observed. 


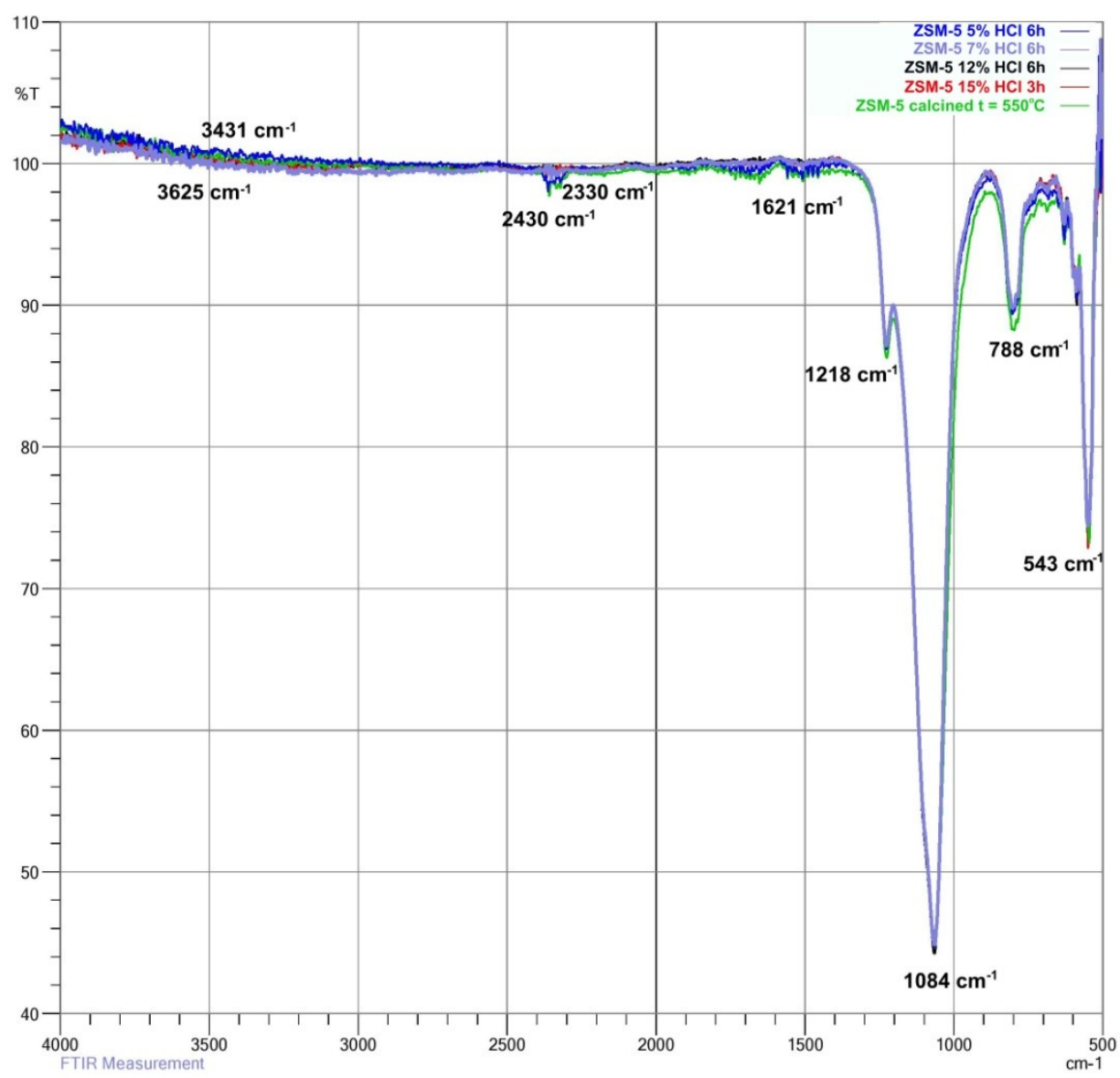

Figure 8. FT-IR spectra of different samples of ZSM-5 zeolite

Slika 8. FT-IR spektri različitih uzoraka zeolita ZSM-5

The structural characteristics of ZSM- 5 zeolites were examined by X-Ray diffraction (Figures 9-10). The obtained peaks, in the range $2 \theta=22.7-25$. $1^{\circ}$, confirm the crystal structure of all analyzed samples of ZSM-5 zeolite $[8,16]$. The qoutient of the calculated areas below the peaks in the range $2 \theta=22.7-25.1^{\circ}$ for each sample separately and the calculated area below the peaks of the standard in the same range $2 \theta$, gives the degree of crystallinity of the zeolite. Based on the obtained values of the degree of crystallinity in the stated range $2 \theta$ (Table 3 ), it can be noticed that the degree of crystallinity decreases with calcination because the degree of crystallinity decreases at a higher aluminium content [17].

The increase in aluminium content in calcined zeolite was also confirmed by the diffractogram in Figure $9 a$, because in the region $2 \theta=8.39-9.62^{\circ}$ there is a more intense peak in calcined zeolite, whose peak intensity corresponds to the presence of aluminium in the zeolite structure. On the other hand, the degree of crystallinity of ZSM-5 zeolite with the $\mathrm{SiO}_{2} / \mathrm{Al}_{2} \mathrm{O}_{3}=1000$ modulus is higher than ZSM-5 zeolite with the $\mathrm{SiO}_{2} / \mathrm{Al}_{2} \mathrm{O}_{3}=400$ modulus, which confirms the fact that increasing silicate modulus increases the degree of crystallinity [17].
Table 3. Comparison of the degree of crystallinity of ZSM-5 samples

Tabela 3. Poređenje stepena kristaličnosti uzoraka ZSM-5

\begin{tabular}{|c|c|}
\hline Sample & Degree of crystallinity, [\%] \\
\hline non-calcined ZSM-5 & 108.69 \\
\hline calcined ZSM-5 & 94.83 \\
\hline ZSM-5 5\% HCl 6h & 91.57 \\
\hline ZSM-5 7\% HCl 6h & 95.51 \\
\hline ZSM-5 10\% HCl 1h & 95.13 \\
\hline ZSM-5 10\% HCl 3h & 90.29 \\
\hline ZSM-5 12\% HCl 6h & 95.51 \\
\hline ZSM-5 15\% HCl 1h & 89.58 \\
\hline ZSM-5 15\% HCl 3h & 90.54 \\
\hline
\end{tabular}

XRD diffractograms for different samples of ZSM-5 zeolite, shown in Figure 9b, exhibit almost identical peaks, except that the zeolite modified with $15 \% \mathrm{HCl}$ undergoes a significant reduction in peak intensities in the region of $2 \theta=22.7-25.1^{\circ}$. This is in accordance with the results shown in Tables $2-3$. Besides, the peaks move along the $2 \theta$ axis to the diffractogram of calcined ZSM- 5 zeolite, so that at lower acid concentrations, i.e. 
with ion exchange with $5 \%$ and $7 \% \mathrm{HCl}$, the peaks move to the left, and in ZSM-5 zeolite with $15 \%$ $\mathrm{HCl}$ and at $3 \mathrm{~h}$ exchange time, they move to the right. The XRD diffractogram of ZSM-5 zeolite at $5 \% \mathrm{HCl}$ and $6 \mathrm{~h}$ exchange time is shifted furthest to the left and indicates that the ion exchange process is dominant and that $5 \% \mathrm{HCl}$ does not lead to the destruction of the crystal structure of the zeolite. On the other hand, the XRD diffractogram of zeolite ZSM- $515 \% \mathrm{HCl} 3 \mathrm{~h}$ was shifted furthest to the right, which is an indicator of the degradation of the crystal lattice in zeolite due to increased acid concentration, i.e. decreased degree of crystallinity (Table 3).

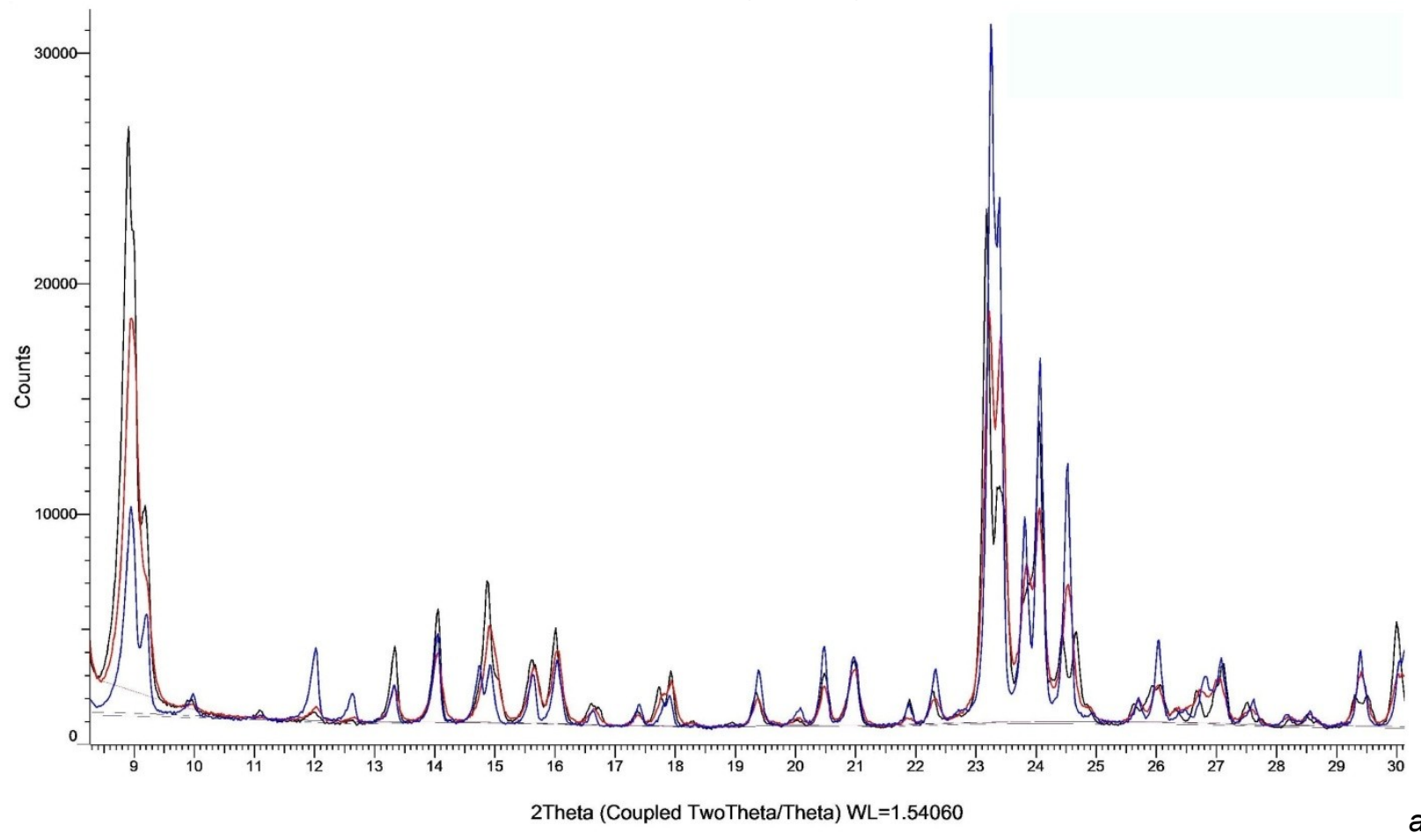

a)

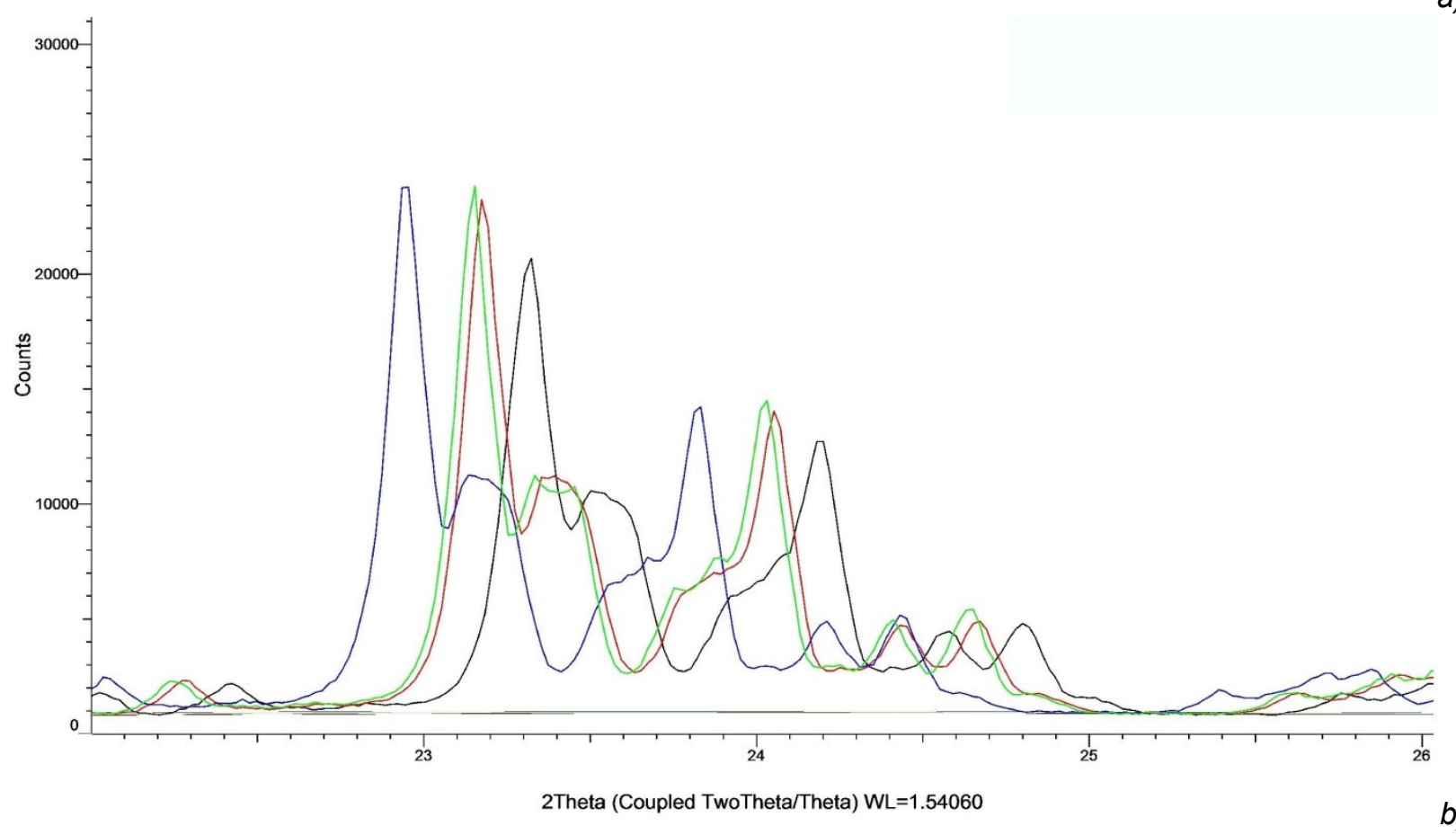

Figure 9. Comparison of XRD diffractograms: a) ZSM-5 standard (-), non-calcined (-) and calcined (-) ZSM-5, b) calcined ZSM-5 (-), ZSM-5 5\% HCl 6h (-),ZSM-5 7\% HCl 6h (-) and ZSM-5 15\% HCl 3h (-)

Slika 9. Poređenje XRD difraktograma: a) ZSM-5 standard (-), nekalcinisani (-) i kalcinisani (-) ZSM-5, b) kalcinisani ZSM-5 (-), ZSM-5 5\% HCl $6 h$ (-),ZSM-5 7\% HCl $6 h$ (-) i ZSM-5 15\% HCl 3h (-) 


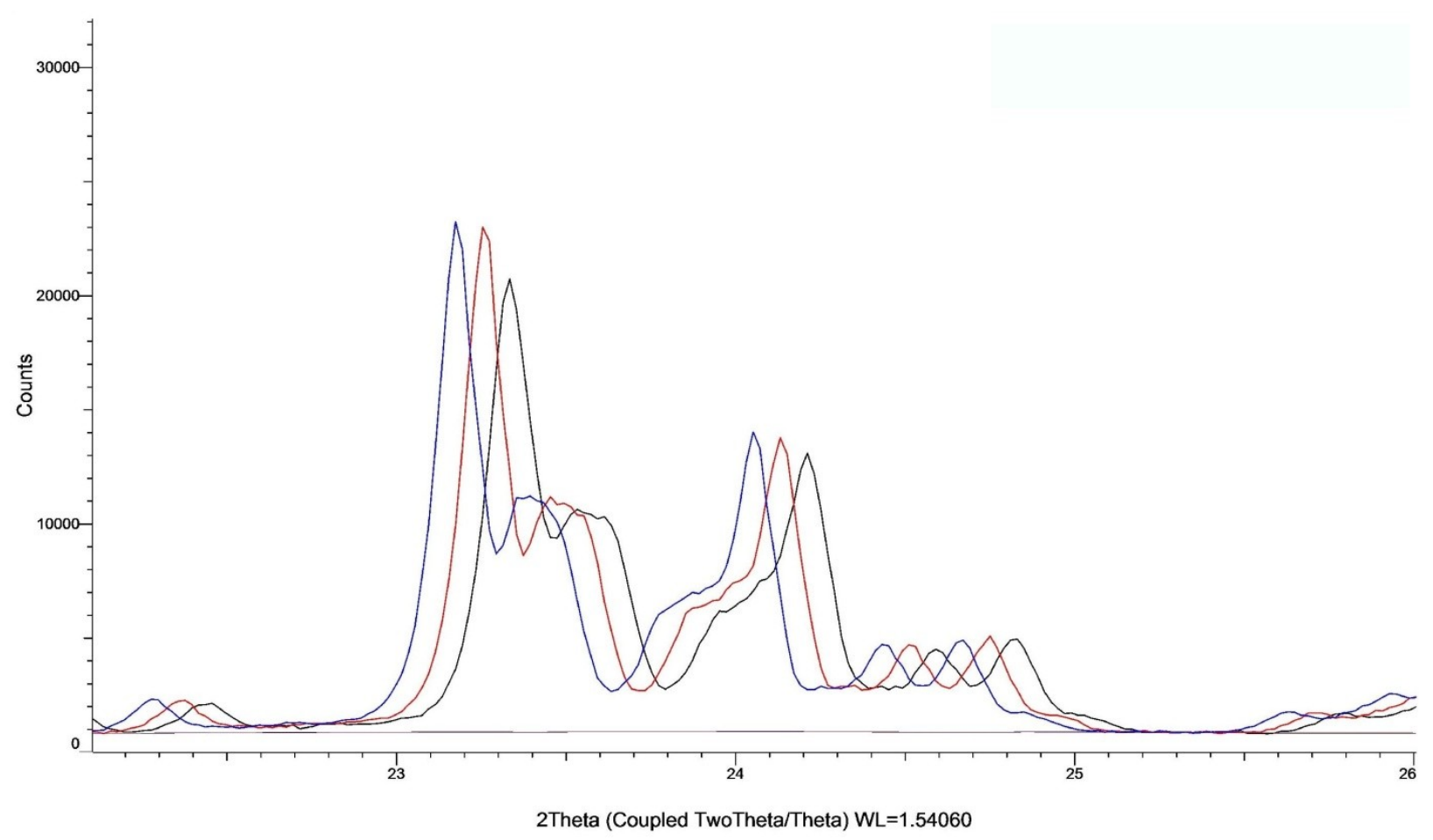

Figure 10. Comparison of XRD diffractograms: calcined ZSM-5 (-), ZSM-5 10\% HCl $1 \mathrm{~h} \mathrm{(-)}$ and ZSM-5 10\% HCl $3 h(-)$

Slika 10. Poređenje XRD difraktograma: kalcinisanog ZSM-5 (-), ZSM-5 10\% HCl $1 \mathrm{~h}$ (-) i ZSM-5 10\% HCl $3 \mathrm{~h}$ (-)
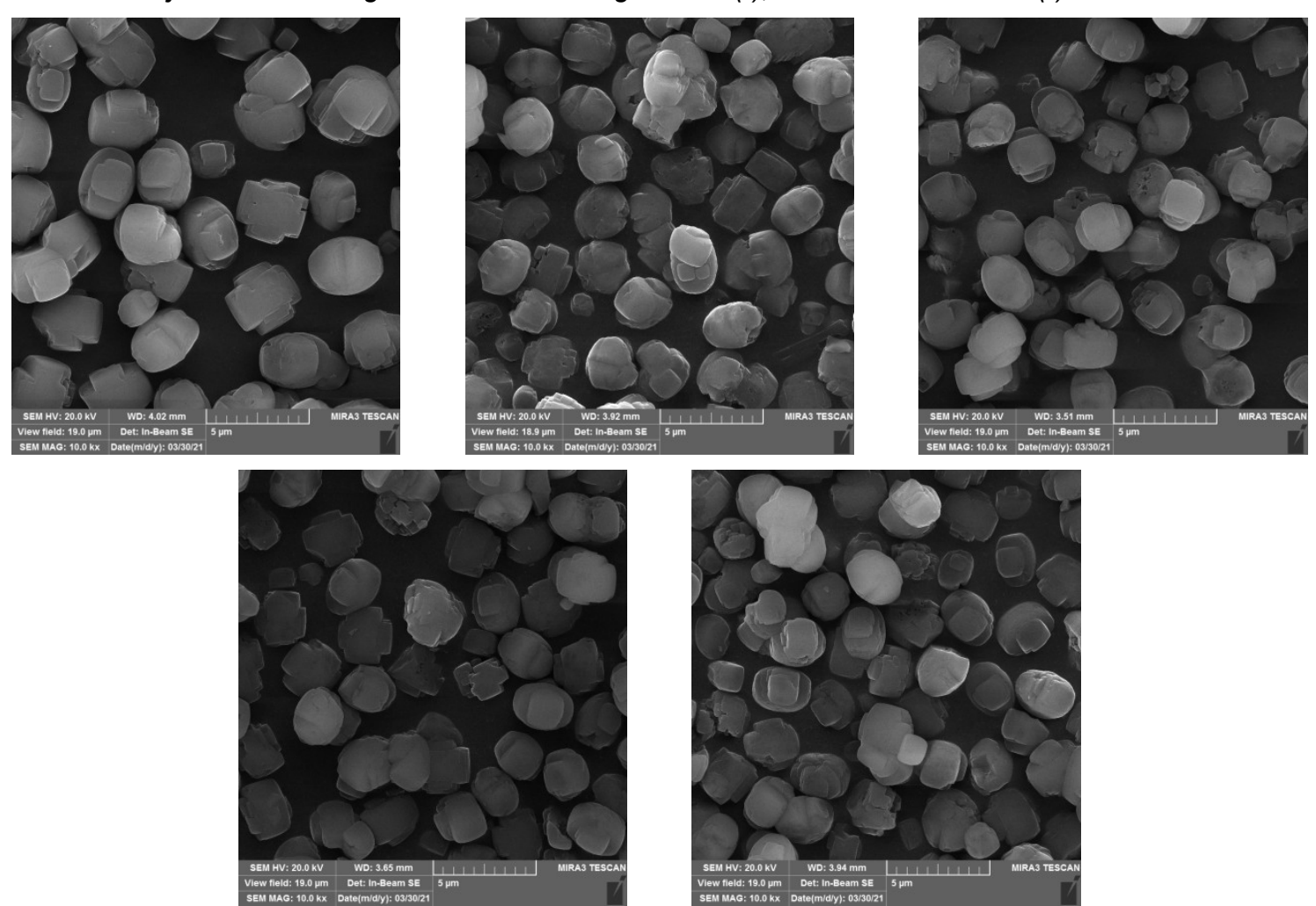

Figure 11. Results of SEM analysis: (a) non-calcined ZSM-5, (b) calcined ZSM-5, (c) ZSM-5 5\% HCl 6h, (d) ZSM-5 10\% HCl 3h, (e) ZSM-5 15\% HCl $3 \mathrm{~h}$

Slika 11. Rezultati SEM analize: (a) nekalcinisanog ZSM-5, (b) kalcinisanog ZSM-5, (c) ZSM-5 5\% HCI 6h, (d) ZSM-5 10\% HCl 3h, (e) ZSM-5 15\% HCl 3h 
It is noticed that the application of $10 \% \mathrm{HCl}$ (Figure 10) with increasing ion exchange time shifts the peaks to the right, which indicates the dominance of the process of partial decomposition of the crystal lattice, and binding of hydrogen ions to aluminium, where aluminium ions are separated from the zeolite structure. Also, with a decrease in the degree of crystallinity, the intensity of peaks in the range $2 \theta=22.7-25.1^{\circ}$ decreases (Table 3 ).

Based on the results presented in Figure 11, it can be observed that there are no significant changes in the morphological characteristics of ZSM-5 zeolite, neither by calcination nor by ion exchange with $\mathrm{HCl}[9,21]$.

\section{CONCLUSIONS}

By reviewing the literature and analyzing the obtained results, it can be concluded that the ion exchange of zeolite $\mathrm{ZSM}-5\left(\mathrm{SiO}_{2} / \mathrm{Al}_{2} \mathrm{O}_{3}=1000\right)$ with hydrochloric acid can reduce the sodium content in the zeolite. Satisfactory results are achieved even with the $5 \% \mathrm{HCl}$, where during the ion exchange of 6 hours, the sodium content drops by $98 \%$ approximately, from $1.1 \%$ to $0.02 \%$. On the other hand, by applying higher concentrations of acid, the same effect can be achieved in a shorter exchange time.

Apart from participating in ion exchange, hydrogen ions present also reduce the aluminium content at higher acid concentrations. Based on this, it can be observed that hydrogen ions have a dual effect on zeolites. On the one hand, they are exchanged with sodium ions, as a result of which zeolites of better acidic properties are obtained, which corresponds to their catalytic application in the processes of the petrochemical industry. The process of sodium ion exchange in ZSM- 5 is dominant at lower concentrations of $\mathrm{HCl}(5 \% \mathrm{HCl}$ and $7 \% \mathrm{HCl}$ ), due to which the change in aluminium content is insignificant. On the other hand, at acid concentrations higher than $7 \%$, hydrogen ions bind to aluminium from the zeolite structure, which leads to certain defects of the crystal lattice of ZSM-5 zeolite. XRD diffractograms confirm the course of these two processes, where the characteristic peaks of ZSM-5 zeolite move along the $2 \theta$ axis, to the left (when the ion exchange reaction with sodium is dominant), and to the right (when the dealumination process is dominant, i.e. when the $\mathrm{Al}-\mathrm{O}$ bond in the crystal lattice breaks).

The obtained values of the degree of crystallinity indicate a decrease in the crystallinity of calcined ZSM-5 compared to non-calcined zeolite due to increased aluminium content, which in turn may be a consequence of removing templates and crystal water from the zeolite structure. In addition, the indicator of partial destruction of the crystal lattice, during ion exchange with $\mathrm{HCl}$ solutions of a higher concentration, is certainly a decrease in the degree of crystallinity.

The results obtained by FT-IR and SEM analyses, in combination with X-Ray diffraction, confirm the possibility of ion exchange with $\mathrm{HCl}$, without significant defects in the crystal structure of ZSM-5 zeolite $\left(\mathrm{SiO}_{2} / \mathrm{Al}_{2} \mathrm{O}_{3}=1000\right)$. However, futher investigations of the possibility of ion exchange of sodium with other, less aggressive acids are advised.

\section{REFERENCES}

[1] J.Dedecek, V.Balgová, V.Pashkova, P.Klein, B.Wichterlová (2012) Synthesis of ZSM-5 zeolites with defined distribution of $\mathrm{Al}$ atoms in the framework and multinuclear MAS NMR analysis of the control of Al distribution, Chemistry of Materials, 24(16), 3231-3239.

[2] V.Leone, P.lovino, E.Coppola, S.Salvestrini, S. Capasso (2016) Sorption of organic pollutants onto zeolitic tuff, Zastita materijala, 57(4), 515-519.

[3] Y. K.Rohayati, R.Sihombing (2017) Synthesis of ZSM- 5 zeolite using Bayat natural zeolite as silica and alumina source, AIP Conference Proceedings, 1862 (1) p. 030094

[4] R.T.Yang (2003) Zeolites and Molecular sieves, in Adsorbents: Fundamentals and Applications; Publisher: John Wiley \& Sons, New Jersey, p. 157 190.

[5] B. Jha, D.N.Singh (2016) Basics of zeolites, in Fly Ash Zeolites; Publisher: Springer, Singapore, p 531 .

[6] J. Weitkamp (2000) Zeolites and catalysis, Solid state ionics, 131(1-2), 175-188.

[7] S.Wang, Y.Peng (2010) Natural zeolites as effective adsorbents in water and wastewater treatment, Chemical engineering journal, 156(1), 11-24.

[8] F.Jin, Y.Fan, M.Yuan, F.Min, G.Wu, Y.Ding, G.F. Froment (2018) Single-event kinetic modeling of ethene oligomerization on ZSM-5, Catalysis Today, 316, 129-141.

[9] L.Shirazi, E.Jamshidi, M.R.Ghasemi (2008) The effect of Si/Al ratio of ZSM-5 zeolite on its morphology, acidity and crystal size. Crystal Research and Technology: Journal of Experimental and Industrial Crystallography, 43(12), 1300-1306.

[10] I. Díaz, E.Kokkoli, O.Terasaki, M.Tsapatsis (2004) Surface structure of zeolite (MFI) crystals. Chemistry of materials, 16(25), 5226-5232.

[11] R.P.Townsend, E.N.Coker (2001) lon exchange in zeolites, in Studies in surface science and catalysis 137; Publisher: Elsevier, Oxford, p. 467524. 
[12] A.A.Zagorodni (2007) lon exchangers, their Structure and Major Properties, in Ion Exchange Materials Properties and Applications, 1st edition; Publisher: Elseiver, Oxford, p 9 - 54.

[13] C.Colella (1996) Ion exchange equilibria in zeolite minerals, Mineralium Deposita, 31 (6), 554-562.

[14] S.O.Jevtić (2015) Sinteza i karakterizacija materijala nastalih modifikacijom prirodnog zeolita (klinoptilolita) i mikroporoznih fosfata sa strukturom zeolita (Synthesis and characterization of materials obtained by modification of natural zeolite (clinoptilolite) and phosphate based microporous materials with zeolitic structure), Doctoral Dissertation, Faculty of Technology and Metallurgy, Belgrade.

[15] E.T.C.Vogt, G.T.Whiting, A.D.Chowdhury, B.M. Weckhuysen (2015) Zeolites and zeotypes for oil and gas conversion, Advances in catalysis, 58, 143314

[16] T.Ma, L.Zhang, Y.Song, Y.Shang, Y.Zhai, Y.Gong (2018). A comparative synthesis of ZSM-5 with ethanol or TPABr template: distinction of Brønsted/Lewis acidity ratio and its impact on $n$ hexane cracking. Catalysis Science \& Technology, 8(7), 1923-1935.
[17] P.J.Danaher, C.Medino, H.Shevchuk, E.M.Zhang (2017) Testing the stability of cation exchanged zeolite ZSM-5 in hot liquid water, dostupno na: https://digital.wpi.edu/downloads/gf06g4038 [Accessed: January 9, 2021]

[18] K.Byrappa, B.V.Kumar (2007) Characterization of Zeolites by Infrared Spectroscopy, Asian Journal od Chemistry,19(6), 4933-4935.

[19] S.A.Paramadini, R.Ekananda, Y.K.Krisnandi (2019) Synthesis and characterization of ZSM-5 zeolite with micro-and hierarchical pore structures from Bayat natural zeolite, IOP Conference Series: Materials Science and Engineering, 496 (1), p 012022.

[20] S.Creci, X.Wang, P.A.Carlsson, M. Skoglundh (2019) Tuned Acidity for Catalytic Reactions: Synthesis and Characterization of $\mathrm{Fe}-$ and Al-MFI Zeotypes, Top Catal, 62, 689-698.

[21] A.S.Araujo, A.O.Silva, M.J.Souza, A.C.Coutinho, J.Aquino, J.A.Moura, A.M. Pedrosa (2005) Crystallization of ZSM-12 zeolite with different Si/Al ratio, Adsorption, 11(2), 159-165.

\section{IZVOD}

\section{JONSKA IZMJENA NATRIJUMA SA HLOROVODONIČNOM KISELINOM NA ZEOLITU ZSM-5}

ZSM-5 zeoliti su visokosilikatni materijali koji imaju značajnu primjenu kod katalitičkih procesa u petrohemiji, naročito zbog visoke selektivnosti. Većina reakcija u petrohemijskoj industriji je katalizovana kiselinama. Kiselinska svojstva zeolita su zavisna od količine kiselih centara, odnosno prisustva vodoničnih jona, te će stoga, u ovom radu biti ispitana mogućnost smanjenja sadržaja natrijuma u porama visokosilikatnog zeolita ZSM-5 sa modulom $\left(\mathrm{SiO}_{2} / \mathrm{Al}_{2} \mathrm{O}_{3}=1000\right)$ primjenom procesa jonske izmjene sa hlorovodoničnom kiselinom. Hemijskom analizom uzoraka prije $i$ poslije jonske izmjene, te primjenom instrumentalnih metoda X-Ray difrakcije, FT-IR spektroskopije i SEM analize praćen je uticaj količine vodoničnih jona na hemijski sastav $i$ promjenu strukture ZSM-5 zeolita pri različitim koncentracijama kiseline, te različitim vremenima jonske izmjene.

Pokazano je da je primjenom jonske izmjene sa hlorovodoničnom kiselinom moguće smanjiti sadržaj natrijuma u zeolitu. Već pri primjeni $5 \% \mathrm{HCl}$ u trajanju od 6 sati postiže se redukcija sadržaja natrijuma u zeolitu od preko $98 \%$. Sličan efekat se postiže pri primjeni koncentrovanijih rastvora hlorovodonične kiseline za kraće vrijeme jonske izmjene. Produženjem vremena jonske izmjene, ne dolazi do znatnijih promjena u pogledu konačne jonske izmjene. S druge strane, primjena rastvora $\mathrm{HCl}$ većih koncentracija dovodi do blagog pada sadržaja aluminijuma u zeolitu, što može djelimično uticati na strukturnu stabilnost zeolita. Rezultati dobijeni FT-IR i SEM analizom, te X-Ray difrakcijom potvrđuju mogućnost jonske izmjene sa hlorovodoničnom kiselinom, bez značajnijih promjena kristalne strukture zeolita.

KIjučne riječi: zeolit, jonska izmjena natrijuma, karakterizacija H-ZSM-5, XRD, FT-IR, SEM.

Naučni rad

Rad primljen: 14. 04. 2021

Rad prihvaćen: 28. 05. 2021.

Rad je dostupan na sajtu: www.idk.org.rs/casopis

(C) 2021 Authors. Published by Engineering Society for Corrosion. This article is an open access article distributed under the terms and conditions of the Creative Commons Attribution 4.0 International license (https://creativecommons.org/licenses/by/4.0/) 